\title{
Global and Regional Financial Integration in Emerging Asia: Evidence from Stock Markets
}

\author{
Guglielmo Maria Caporale ${ }^{1+}$, Luis A. Gil-Alana², and Kefei You ${ }^{3}$ \\ ${ }^{1}$ Brunel University London, UK \\ ${ }^{2}$ University of Navarra, Spain \\ ${ }^{3}$ University of Greenwich, UK
}

\begin{abstract}
This paper investigates if financial markets in emerging Asia have become more globally or regionally integrated since the Asian financial crisis in the late 1990s. It employs a price-based measure of integration, namely, stock return differentials, between 10 emerging Asian economies and the United Stated (US) (as an indicator of global integration), as well as Japan and the Asian region (as two alternative indicators of regional integration), to test for mean reversion and draw inferences regarding financial integration. This paper makes a three-fold contribution to the literature. It uses not only aggregate but also industry-level data on stock returns, it examines the impact of the 2008 crisis, and it adopts a more general fractional integration approach. The evidence suggests that in emerging Asia, on both the aggregate and industry (especially for the financial sector) levels, there is more regional than global integration, and that the former became even stronger during the post-2008 crisis period. Furthermore, Japan's influence has been declining and the Chinese stock market has become more integrated, both regionally and globally.
\end{abstract}

Keywords: Global and regional integration, Asian stock markets, Fractional integration, Global financial crisis JEL Classifications: F31, C22

Received 9 November 2019, Revised 8 September 2020, Accepted 25 February 2021

\section{Introduction}

Since the 1997 Asian financial crisis and information technology bubble at the turn of the century, Asian stock markets have rebounded strongly, peaking in November 2007 and then plunging by $41.9 \%$ (in United States (US) dollars) one year later with the onset of the 2008 global financial crisis (Figure 1). They again recovered at an astonishing speed and by 2016, accounted for nearly a quarter (23.2\% in US dollars) of the capitalization of global stock markets (World Federation of Exchange, 2016). The greater impact on Asian stock markets of the 2008

\footnotetext{
+Corresponding Author: Guglielmo Maria Caporale

Professor, Department of Economics and Finance, Brunel University London, UB8 3PH, UK.

Email: Guglielmo-Maria.Caporale@brunel.ac.uk

Co-Author: Luis A. Gil-Alana

Professor, University of Navarra, Campus Universitario, 31009 Pamplona, Navarra, Spain. Email: alana@unav.es

Co-Author: Kefei You

Associate Professor, University of Greenwich, Park Row, Greenwich, SE10 9LS, UK. Email: k.you@greenwich.ac.uk
} 
global financial crisis, originating in the US, compared to the 1997 Asian financial crisis (both in terms of the speed and the size of the decline in daily stock prices; see Hinojales \& Park, 2011) raises the question whether Asian financial markets have become more globally than regionally integrated over the past two decades. While financial integration generally has positive implications for capital allocation efficiency (Pauer, 2005), promoting financial development, and enhancing economic growth (Fung et al., 2008), stronger financial linkages may also imply greater cross-border financial contagion risk, with adverse consequences for financial stability and economic growth. For developing Asia, assessing and monitoring financial integration is of particular importance not only because of its great potential benefits, given the fact that the outstanding stock to credit ratio remains lower than that of developed economies (Almekinders et al., 2015), but also because developing Asia is characterized by poor risk management and overexposure to cyclical economic activity (Almekinders et al., 2015; Schipke, 2015).

Figure 1. Stock market index for Asia (MSCI AC Asian Index) (1996M10-2016M8)

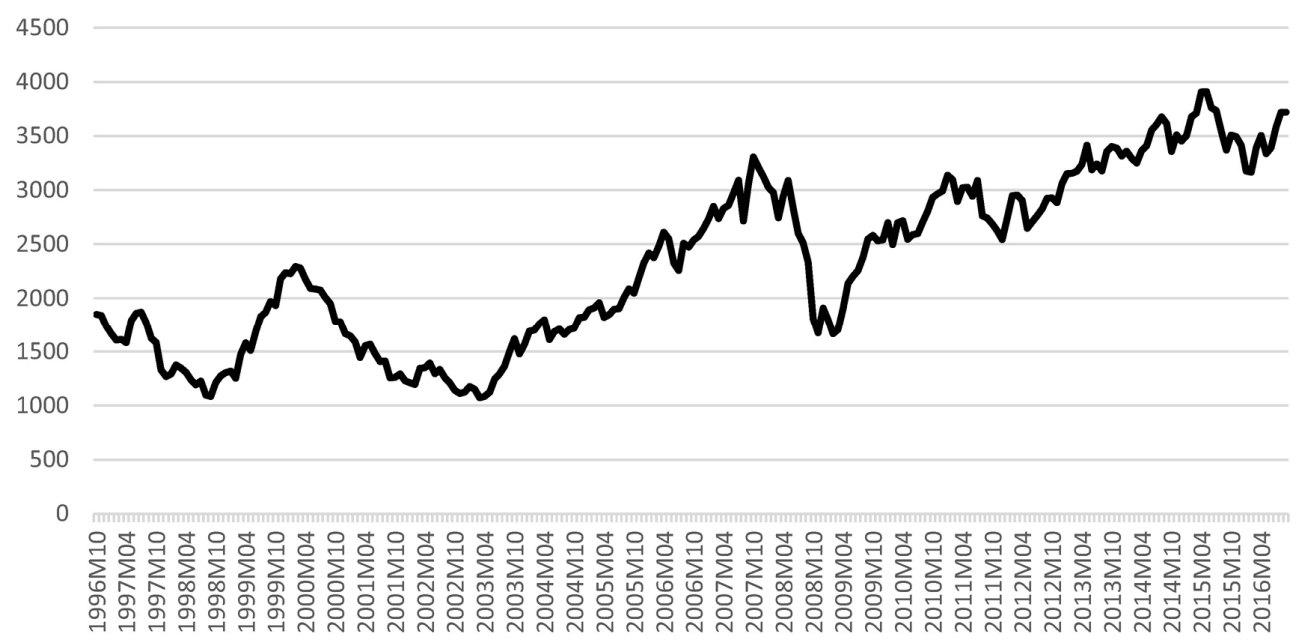

Note: Countries in the MSCI AC Asian Index include: China, Hong Kong, India, Indonesia, Korea, Malaysia, Philippines, Singapore, Taiwan and Thailand.

This paper assesses the extent of financial integration in developing Asia and investigates whether it is globally or regionally integrated. It employs a price-based measure of integrationnamely, stock return differentials between 10 emerging Asian economies and the US (as an indicator of global integration), as well as between emerging Asian economies and Japan or the Asian region (as two alternative indicators of regional integration) - to test for mean reversion and draw inferences regarding the extent of global and regional financial integration. It makes a three-fold contribution to the literature on stock market integration in emerging Asia. First, it uses not only aggregate but also industry-level data on stock returns and therefore provides information on the role of specific sectors in the process of financial integration (very few 
studies have analyzed Asian stock market integration using industry-level data; see Hinojales \& Park, 2011).

Second, it examines the impact of the 2008 crisis on regional and global integration in Asian stock markets (at both the aggregate and industry levels). Again, only a few other studies have previously addressed this issue. Wu et al. (2015) and Wang (2014) both used daily data at the aggregate level. The former focused on the transmission of shocks (i.e., contagion) from the US, Japan, and Hong Kong to other Asian countries and therefore did not consider the regional integration of East Asian stock markets or industry-level evidence.

Third, unlike previous studies using either correlation tests or vector autoregression (VAR) techniques, ${ }^{1)}$ this study employs a fractional integration approach as in Gil-Alana (2000) and Caporale and Gil-Alana (2017). A fractional differencing parameter $\mathrm{d}$ less than one in the return differentials does not necessarily imply mean reversion, which would indicate stock market integration - only values below zero represent evidence of integration, while values above zero imply long memory in the return differentials (i.e., no stock market integration. To our knowledge, fractional integration tests have not been previously performed in the case of emerging Asian stock market returns, despite their advantage over conventional methods based on the classical $\mathrm{I}(0) / \mathrm{I}(1)$ dichotomy.

The layout of this paper is as follows. Section 2 briefly reviews the relevant literature. Section 3 outlines the methodology. Section 4 describes the data. Section 5 presents the empirical results. Section 6 offers some concluding remarks.

\section{Literature Review}

Various indices have been employed in the existing literature to measure financial integration. Broadly speaking there are three types of measures: (1) price-based measures that are largely embodied in interest parity conditions in the money markets as well as in co-movements in assets returns in stock and bond markets; (2) volume-based measures that include the saving-investment correlations pioneered by Feldstein and Horioka (1980), consumption correlations (e.g., Bayoumi, 1997; de Browuer, 1999) and capital flows (cross-border financial transactions) (Cavoli et al., 2006); (3) measures based on regulatory or institutional factors, capital controls and legal restrictions such as those on foreign equity holdings (e.g., Grilli \& Milesi-Ferretti, 1995; Magud \& Reinhart, 2006).

In addition, Kearney and Lucey (2004) put forth a measure based on the concept of international capital market completeness (Stockman, 1988), and Baele et al. (2004) considered news-based

1) Another strand of the literature on stock market integration examines volatility spillover; see Sharma and Seth (2012) for an extensive review. 
measures that tested whether returns on assets between countries were influenced by local or worldwide news as an indication of financial integration (see Baltzer et al. (2008) for a similar approach). Volosovych $(2011,2013)$ suggested a price-based measure that is an integration index in the context of capital market integration obtained using dynamic principal component analysis (see also Donadelli \& Paradiso (2014)).

Our focus is on studies using price-based measures for the Asian stock markets since they are the most widely used for financial integration (Kearney \& Lucey, 2004; Sharma \& Seth, 2012). Typically, (time-varying) correlation analysis and VAR estimation (including Granger causality tests, variance decompositions, impulse responses, and cointegration tests) are conducted on stock market returns. More recently, (time-varying) correlation analysis has been applied. For instance, Loh (2013) investigated the co-movement of 13 Asia-Pacific stock market returns using the wavelet coherence method for the January 2001-March 2012 period and found evidence of long-term co-movement between most of the Asia-Pacific stock markets as well as between them and both Europe and the US. Abid et al. (2014) tested a conditional version of the International Capital Asset Pricing Model (ICAPM) using pre-2008 data for five major Asian countries and estimating a multivariate General Dynamic Covariance-GARCH model; their results support the validity of the ICAPM and indicate that risk is priced at the regional level. Again, testing the ICAPM, Boubakri and Guillaumin (2015) found segmented stock markets until 2008 and an upward trend in regional integration between the East Asian stock markets using GARCH-dynamic conditional correlations (DCCs) and data from 1990M1 to 2012M8. Narayahet et al. (2014) also estimated a GARCH-DCC model to investigate the patterns of stock market integration of four emerging Asian nations vis-à-vis the US, Australia, China, and India over the period 2001M1-2012M3; they found stronger correlations during the 2007-2009 crisis period. Cao et al. (2017) performed a volatility-constrained, multifractal, de-trended, cross-correlation analysis and highlighted the key role of the Hong Kong stock market. Wang et al. (2017) applied a coupling de-trended fluctuation analysis method to four Asian stock markets and discovered evidence of financial integration.

Some recent VAR studies on the Asian stock markets include Huyghebaert and Wang (2010) and Wang (2014), who examined long- and short-term linkages using cointegration tests and impulse response analysis, respectively. Studies focusing on individual Asian countries include Gupta and Guidi (2012) on India and Chien et al. (2015) on China, both using cointegration techniques (DCC analysis was also performed in the former).

The overall conclusion of the aforementioned papers is that financial integration between the Asian stock markets has increased and that the linkages between them have become stronger as a result of shocks. Some recent studies have investigated whether the higher degree of financial integration observed in Asian stock markets is global or regional (e.g., Hinojales \& Park, 2011; Park \& Lee, 2011; Kim et al., 2011; Kim \& Lee, 2012; Park, 2013). They generally 
used correlation analysis and concluded that most of the integration is predominantly global, although regional integration has also increased.2)

In contrast to the aforementioned studies, the present one measures integration using stock return differentials between Asian economies and the US (as an indicator of global integration), or between Asian economies and Japan or a regional index (as two alternative indicators of regional integration). We then conduct fractional integration tests (Gil-Alana, 2000, 2004) on the return differentials to examine their mean-reversion properties and obtain evidence on global and/or regional integration. ${ }^{3)}$ Further, we assess the impact of the 2008 global financial crisis, which is much less studied than the 1997 Asian crisis, and perform both aggregate and sectoral analysis. $^{4)}$

\section{Methodology}

The fractional integration framework adopted in this study enables the differencing parameter required to make a time series stationary or $\mathrm{I}(0)$ any real number (as opposed to an integer): a series $x_{t}, t=1,2, \ldots$ is said to be integrated of order $d$, and it is denoted as $I(d)$, if it can be represented, as follows:

$$
(1-\mathrm{L})^{\mathrm{d}} \mathrm{x}_{\mathrm{t}}=\mathrm{u}_{\mathrm{t}}, \mathrm{t}=1,2, \ldots,
$$

where $x_{t}$ is the observed series, $L$ the lag operator (i.e., $L x_{t}=x_{t-1}$ ), and $u_{t}$ is $I(0)$ and assumed to be a covariance stationary process with a finite sum of autocovariances. In this context, a process is defined as "mean-reverting" if $\mathrm{d}$ is less than 1 ; this framework is more general than standard approaches that only consider mean reversion in the case of $d=0$. In addition, the lower the value of $\mathrm{d}$ in the interval $[0,1)$, the faster the convergence process. In addition, if $\mathrm{d}$ is greater than 0 , the process is said to exhibit "long memory" because of the strong degree

2) In addition to correlation analysis, other techniques such as factor analysis (e.g., Hinojales \& Park, 2011) and convergence tests (e.g., Park, 2013) have also been employed in previous studies comparing the global and regional integration of Asian stock markets.

3) In terms of Asia, some recent examples of mean-reverting analysis of stock prices using techniques alternative to conventional ADF unit root tests include Chen and Kim (2011), who employed non-linear mean reversion tests, and Wang et al. (2015), who used a Lagrange Multiplier Fourier unit root test and a stationary test with a Fourier function.

4) Wu et al. (2015) and Wang (2014) examined the role of the recent financial crisis in Asian stock market integration. Both used daily aggregate-level data. The former focused on the transmission of shocks (contagion) from the US, Japan, and Hong Kong to other Asian countries; therefore, regional integration in East Asian stock markets is not explained. The latter employed cointegration tests and impulse response analysis. Compared with the latter and the other studies previously mentioned that also covered the post-2008 crisis period, our study adopts alternative measures of financial integration and empirical methods, and we also provide further industry-level evidence. 
of association between observations that are far away in time, and covariance stationarity holds if $\mathrm{d}$ is less than 0.5 . Therefore, if $\mathrm{d}$ belongs to the interval $[0.5,1)$, the process is non-stationary but mean-reverting. 5 )

From this outline of the fractional integration approach, it is clear that this method outperforms classical ones that are based exclusively on integer degrees of differentiation, such as in the stationary $\mathrm{I}(0)$ and the non-stationary $\mathrm{I}(1)$ cases, since it allows for a wider range of alternatives and a much richer degree of flexibility in the specification of the series. The $I(d)$ approach also differs from other methods such as wavelets since it focuses only on the long run or zero frequency; that is, the spectral density function of $x_{t}$ in (1) tends to infinity as the frequency approaches zero for $d<0$. This is, in fact, the original finding by Granger (1980) and others, who demonstrated that many aggregate economic series exhibited a spectrum with very large values at the smallest frequency, which suggests that first differences should be taken; however, first differencing produced spectrums with values close to zero at the zero frequency, an indication of overdifferentiation.6) Specifically, we consider the following regression model,

$$
\mathrm{y}_{\mathrm{t}}=\beta_{0}+\beta_{1} \mathrm{t}+\mathrm{x}_{\mathrm{t}}, \mathrm{t}=1,2, \ldots
$$

where $y_{t}$ is the series of interest, $\beta_{0}$ and $\beta_{1}$ are unknown coefficients on an intercept and a linear time trend, and the regression errors, $x_{t}$, are specified as in Equation (1), that is, as integrated of order $\mathrm{d}$, where $\mathrm{d}$ is also an unknown parameter to be estimated. The estimation method for all parameters is the Whittle function in the frequency domain as in Dahlhaus (1989). Other approaches produce very similar results.

\section{Data Description}

The emerging Asian stock markets examined are those of the People's Republic of China (PRC), Hong Kong, India, Indonesia, Malaysia, the Philippines, Singapore, South Korea, Taiwan, and Thailand. We calculate the stock market return differentials between each of the 10 emerging Asian economies and the following three benchmarks:

a) the US, to examine global financial integration;

b) Japan, to examine regional financial integration, since it has long been regarded as the regional leader in terms of financial market development; and

5) Note that non-stationarity refers to the variance. In the $I(d)$ context, the variance of the partial sums increases with $\mathrm{d}$.

6) See Robinson (1978), Granger (1980), Granger and Joyeux (1980), and Hosking (1981), among others, for seminal studies on fractional integration. 
c) Morgan Stanley Capital International (MSCI) Asia (excluding Japan), as an alternative benchmark for examining regional financial integration.

Stock market returns are calculated as monthly log first differences of stock indices. The stock indices are collected from Datastream monthly and cover the 2000M1-2016M8 period.

As previously mentioned, in addition to aggregate data, we also analyze industry-level data. Due to data unavailability, we were not able to include all 10 industry stock indices7) in our group of emerging Asian economies. Therefore, using the same data sources and methods as for the aggregate stock indices, we calculate three sets of differentials for three industries - industrials, consumer goods, and financials - which are the most developed industries in developing Asia.

To examine the impact of the 2008 financial crisis on both global and regional integration, we divide the sample into two sub-periods-2000M1-2007M12 and 2009M1-2016M8, excluding 2008, when markets were very volatile. Therefore, for each emerging Asian economy, we obtain 24 stock return differentials (i.e., three benchmarks; four stock indices, one aggregate, and three at the industry level; two sub-periods).

\section{Empirical Results}

The results are presented in Tables 1-4, with the aggregate results in Table 1 and the disaggregated results in Tables 2-4. As expected, most of the return differentials are $\mathrm{I}(0)$ processes, which implies a unit root in the original series. We focus, in particular, on cases of long memory $(d>0)$ in the return differentials, which indicates high persistence $(d>1)$ in the original series, and on cases of anti-persistence $(d<0)$, which implies mean reversion $(d<1)$ in the original series and therefore integrated markets.

\section{A. Asian stock markets: full sample and pre- and post-crisis results}

Table 1 presents the estimates of $d$ for three sets of return differentials at the aggregate level. For the entire sample period, 2001M1-2016M8, long memory in return differentials $(d>0)$ or high persistence in the original series $(d>1)$ is only found for Indonesia vis-à-vis the US (see Columns (1), (4), and (7)). By contrast, there is evidence of anti-persistence $(d<0)$ or mean reversion $(d<1)$ in the original series in a few cases, namely, Hong Kong vis-à-vis the US and Asia as well as India, Taiwan, and Thailand vis-à-vis Asia.

The sub-sample results are presented in the rest of Table 1's columns. In the pre-crisis

7) According to the MSCI, the 10 industry indices are for the following industries: 1) Basic Materials, 2) Consumer Goods, 3) Consumer Services, 4) Financials, 5) Healthcare, 6) Industrials, 7) Oil \& Gas, 8) Technology, 9) Telecommunications, and 10) Utilities. 
period (2001M1-2007M12), long memory $(d>0)$ or high persistence in the original series $(d>1)$ is only found for China vis-à-vis Japan (as indicated in Column (5)), while there is evidence of anti-persistence $(d<0)$ or mean reversion $(d<1)$ in various cases, specifically, Hong Kong, India, and the Philippines vis-à-vis the US, and Hong Kong and India vis-à-vis Asia (as indicated in Columns (2) and (8), respectively).

In the post-crisis period (2009M1-2016M12), anti-persistence is not found in any case vis-à-vis the US and Japan. The only evidence of mean reversion is obtained for Singapore, Taiwan, and Thailand vis-à-vis Asia (see Column (9)). Further, it appears that there is long memory or high persistence in the original series in the case of Malaysia vis-à-vis Asia.

Two points are noteworthy. First, there is no evidence of integration between the emerging Asian economies considered and Japan, either during the entire sample period or the sub-periods.

Table 1. Estimates of $d$ for the Whole Period (2000M1-2016M8) and Two Sub-Samples (2000M1-2007M12, 2009M1-2016M12): Aggregate Data

\begin{tabular}{|c|c|c|c|c|c|c|c|c|c|}
\hline & \multicolumn{9}{|c|}{ Aggregate Data } \\
\hline & \multicolumn{3}{|c|}{ Against US } & \multicolumn{3}{|c|}{ Against Japan } & \multicolumn{3}{|c|}{ Against Asia regional index } \\
\hline & (1) & (2) & (3) & (4) & (5) & (6) & (7) & $(8)$ & (9) \\
\hline & $\begin{array}{l}\text { Whole } \\
\text { Period }\end{array}$ & $1^{\text {st }}$ subs. & $2^{\text {nd }}$ subs. & $\begin{array}{l}\text { Whole } \\
\text { Period }\end{array}$ & $1^{\text {st }}$ subs. & $2^{\text {nd }}$ subs. & $\begin{array}{l}\text { Whole } \\
\text { Period }\end{array}$ & $1^{\text {st }}$ subs. & $2^{\text {nd }}$ subs. \\
\hline CHINA & $\begin{array}{c}0.02 \\
(0.061)\end{array}$ & $\begin{array}{c}0.07 \\
(0.079)\end{array}$ & $\begin{array}{c}-0.04 \\
(0.097)\end{array}$ & $\begin{array}{c}-0.01 \\
(0.061)\end{array}$ & $\begin{array}{c}0.11 \\
(0.081)\end{array}$ & $\begin{array}{c}-0.14 \\
(0.087)\end{array}$ & $\begin{array}{c}0.02 \\
(0.061)\end{array}$ & $\begin{array}{c}0.10 \\
(0.096)\end{array}$ & $\begin{array}{c}-0.06 \\
(0.091)\end{array}$ \\
\hline HONG KONG & $\begin{array}{c}-0.09 * * * \\
(0.048)\end{array}$ & $\begin{array}{c}-0.26^{* * * *} \\
(0.146)\end{array}$ & $\begin{array}{c}-0.12 \\
(0.128)\end{array}$ & $\begin{array}{c}-0.04 \\
(0.067)\end{array}$ & $\begin{array}{c}0.03 \\
(0.152)\end{array}$ & $\begin{array}{c}-0.06 \\
(0.114)\end{array}$ & $\begin{array}{c}-0.15 * * \\
(0.060)\end{array}$ & $\begin{array}{c}-0.16^{* * * *} \\
(0.089)\end{array}$ & $\begin{array}{c}-0.10 \\
(0.091) \\
\end{array}$ \\
\hline INDIA & $\begin{array}{c}-0.07 \\
(0.012)\end{array}$ & $\begin{array}{c}-0.20 * * * \\
(0.104)\end{array}$ & $\begin{array}{c}0.02 \\
(0.115)\end{array}$ & $\begin{array}{c}-0.04 \\
(0.073)\end{array}$ & $\begin{array}{c}-0.15 \\
(0.127)\end{array}$ & $\begin{array}{c}0.10 \\
(0.110)\end{array}$ & $\begin{array}{l}-0.21^{*} \\
(0.067)\end{array}$ & $\begin{array}{c}-0.33 * \\
(0.114)\end{array}$ & $\begin{array}{c}-0.06 \\
(0.085)\end{array}$ \\
\hline INDONESIA & $\begin{array}{c}0.09 \\
(0.073)\end{array}$ & $\begin{array}{c}-0.02 \\
(0.109)\end{array}$ & $\begin{array}{c}0.13 \\
(0.128)\end{array}$ & $\begin{array}{c}0.07 \\
(0.079)\end{array}$ & $\begin{array}{c}0.00 \\
(0.129)\end{array}$ & $\begin{array}{c}0.10 \\
(0.090)\end{array}$ & $\begin{array}{c}-0.06 \\
(0.080)\end{array}$ & $\begin{array}{c}-0.09 \\
(0.154)\end{array}$ & $\begin{array}{c}-0.17 \\
(0.146)\end{array}$ \\
\hline MALAYSIA & $\begin{array}{c}-0.03 \\
(0.079)\end{array}$ & $\begin{array}{c}-0.03 \\
(0.133)\end{array}$ & $\begin{array}{c}-0.13 \\
(0.127)\end{array}$ & $\begin{array}{c}0.00 \\
(0.068)\end{array}$ & $\begin{array}{c}0.01 \\
(0.110)\end{array}$ & $\begin{array}{c}-0.03 \\
(0.019)\end{array}$ & $\begin{array}{c}0.02 \\
(0.068)\end{array}$ & $\begin{array}{c}-0.09 \\
(0.152)\end{array}$ & $\begin{array}{c}0.10 \\
(0.091)\end{array}$ \\
\hline PHILIPPINES & $\begin{array}{c}-0.07 \\
(0.067) \\
\end{array}$ & $\begin{array}{c}-0.22 * * \\
(0.112)\end{array}$ & $\begin{array}{c}-0.06 \\
(0.109)\end{array}$ & $\begin{array}{c}-0.02 \\
(0.060) \\
\end{array}$ & $\begin{array}{c}-0.19 \\
(0.109) \\
\end{array}$ & $\begin{array}{c}0.05 \\
(0.099)\end{array}$ & $\begin{array}{c}-0.01 \\
(0.085)\end{array}$ & $\begin{array}{c}-0.09 \\
(0.157) \\
\end{array}$ & $\begin{array}{c}-0.11 \\
(0.109)\end{array}$ \\
\hline SINGAPORE & $\begin{array}{c}0.02 \\
(0.061)\end{array}$ & $\begin{array}{c}-0.11 \\
(0.111)\end{array}$ & $\begin{array}{c}0.06 \\
(0.098)\end{array}$ & $\begin{array}{c}0.02 \\
(0.067)\end{array}$ & $\begin{array}{c}-0.03 \\
(0.145)\end{array}$ & $\begin{array}{c}0.05 \\
(0.096)\end{array}$ & $\begin{array}{c}-0.07 \\
(0.085)\end{array}$ & $\begin{array}{c}-0.09 \\
(0.140) \\
\end{array}$ & $\begin{array}{c}-0.23 * * * \\
(0.134)\end{array}$ \\
\hline SOUTH KOREA & $\begin{array}{c}0.03 \\
(0.061) \\
\end{array}$ & $\begin{array}{c}0.03 \\
(0.103)\end{array}$ & $\begin{array}{c}-0.07 \\
(0.097)\end{array}$ & $\begin{array}{c}0.00 \\
(0.061) \\
\end{array}$ & $\begin{array}{c}-0.02 \\
(0.133) \\
\end{array}$ & $\begin{array}{c}0.05 \\
(0.085) \\
\end{array}$ & $\begin{array}{c}0.03 \\
(0.080) \\
\end{array}$ & $\begin{array}{c}0.07 \\
(0.120) \\
\end{array}$ & $\begin{array}{c}-0.17 \\
(0.119)\end{array}$ \\
\hline TAIWAN & $\begin{array}{c}-0.09 \\
(0.085)\end{array}$ & $\begin{array}{c}-0.11 \\
(0.122)\end{array}$ & $\begin{array}{c}-0.05 \\
(0.084)\end{array}$ & $\begin{array}{c}-0.09 \\
(0.072)\end{array}$ & $\begin{array}{c}-0.14 \\
(0.121)\end{array}$ & $\begin{array}{c}-0.01 \\
(0.090)\end{array}$ & $\begin{array}{c}-0.15 * * * \\
(0.086)\end{array}$ & $\begin{array}{c}-0.14 \\
(0.133)\end{array}$ & $\begin{array}{c}-0.55^{*} \\
(0.136)\end{array}$ \\
\hline THAILAND & $\begin{array}{c}-0.05 \\
(0.067)\end{array}$ & $\begin{array}{c}-0.07 \\
(0.097)\end{array}$ & $\begin{array}{c}-0.05 \\
(0.085)\end{array}$ & $\begin{array}{c}0.01 \\
(0.067)\end{array}$ & $\begin{array}{c}-0.07 \\
(0.104)\end{array}$ & $\begin{array}{c}0.02 \\
(0.130)\end{array}$ & $\begin{array}{c}-0.11 * * * \\
(0.057)\end{array}$ & $\begin{array}{c}-0.14 \\
(0.098)\end{array}$ & $\begin{array}{l}-0.23 * * \\
(0.121)\end{array}$ \\
\hline
\end{tabular}

Note: The standard errors appear in parentheses. Three models are employed in the estimation of d: a) no deterministic items, b) intercept, and c) a linear trend. Values included in this table are based on the most significant model out of the three for each series, according to the deterministic terms and the type of $\mathrm{I}(0)$ disturbance. The results with $* * *$, and $* * *$ correspond to cases of anti-persistence $(d<0)$ at the $95 \%$ level, which implies integrated markets, respectively, for $p<0.1, p<0.05$, and $p<0.01$. 
This probably reflects the power shift witnessed in East Asia over the past two decades, with the rise of China and the relative decline of Japan (Yang, 2010), which was hit by the 2008 global financial crisis while it was still in the midst of a slow recovery from economic stagnation (Grimes, 2009).

Second, regional rather than global integration appears to be predominant over the full sample when the regional index (excluding Japan) is used as the benchmark. In the pre-crisis period, global is stronger than regional integration, but the opposite is true in the post-crisis period, during which no cases of global integration are found, but there is stronger regional integration. Since the Asian financial crisis, Asian policymakers have encouraged greater financial cooperation and integration within the region by introducing a range of initiatives (e.g., Chiang Mai Initiative Multilateralization, Asian Bond Market Initiative) and promoting financial forums (e.g., Association of Southeast Asian Nations Plus Three, the Executives' Meeting of East Asia-Pacific Central Banks) (Ananchotikul et al., 2015). The Association of Southeast Asian Nations (ASEAN) has outlined plans to foster capital market integration by building the capital market infrastructure and harmonizing regulations (Almekinders et al., 2015). The uncertainty and volatility transmitted from the US to the rest of the world during the 2008 financial crisis have pushed investors toward a more inward-looking view (Rughoo \& You, 2016) and Asian countries toward even closer regional cooperation and integration (Asian Development Bank, 2013).

We further compare the values of $d$ during the pre- and post- crisis periods in Table 1 . An increase in d (i.e., a move away from stock market integration) can be observed in the case of Hong Kong, India, and the Philippines vis-à-vis the US; there is instead a decrease in $d$ (a move toward stock market integration) in the case of China vis-à-vis Japan, but these two stock markets are still not integrated. Finally, there is an increase in d for Hong Kong, India, and Malaysia and a decrease for Singapore, Taiwan, and Thailand vis-à-vis the Asian regional index. This confirms the relative decline of Japan and stronger regional integration after the crisis. It is also interesting to note that Hong Kong and India appear to be integrated with both the US and regional (excluding Japan) stock markets before, but not after, the crisis. In the case of Hong Kong, this probably reflects the greater influence of mainland China after the 2008 financial crisis, although it is still less important than that of the US (He et al., 2009), despite the lower impact of US equity returns (see Glick \& Hutchison, 2013). India has been less involved in the various initiatives previously mentioned aimed at increasing regional integration.

\section{B. Industry-level results}

\section{Industrial sector}

For the industrial sector (Table 2), focusing on the results for the entire period (Columns 
(1), (4), and (7)), there is evidence of long memory only for South Korea vis-à-vis Asia and of anti-persistence (or mean reversion in the original series) only for Hong Kong and Thailand vis-à-vis the US and Asia, Thailand vis-à-vis Japan, and Taiwan vis-à-vis Asia. Regional integration appears to be stronger than global integration when the regional index (excluding Japan) is employed for the analysis.

During the pre-crisis period (Columns (2), (5), and (8)), there is no evidence of long memory, while anti-persistence is found for Thailand vis-à-vis the US, Japan, and Asia, and for Hong Kong and Malaysia vis-à-vis the US. During the post-crisis period (Columns (3), (6), and (9)), there is no evidence of integration with the US, while there appears to be integration for Hong Kong and Malaysia vis-à-vis Japan and China and Taiwan vis-à-vis Asia. Evidence of long memory is found only for Indonesia vis-à-vis the US. Global integration seems to be stronger than regional integration prior to the 2008 crisis and the opposite is true during the following period.

Table 2. Estimates of $d$ for the Whole Period (2000M1-2016M8) and Two Sub-Samples (2000M1-2007M12, 2009M1-2016M12): Industrial Sector Data

\begin{tabular}{|c|c|c|c|c|c|c|c|c|c|}
\hline & \multicolumn{9}{|c|}{ Industrials sector } \\
\hline & \multicolumn{3}{|c|}{ Against US } & \multicolumn{3}{|c|}{ Against Japan } & \multicolumn{3}{|c|}{ Against Asia regional index } \\
\hline & (1) & (2) & (3) & (4) & (5) & (6) & (7) & $(8)$ & (9) \\
\hline & $\begin{array}{l}\text { Whole } \\
\text { Period }\end{array}$ & $1^{\text {st }}$ subs. & $2^{\text {nd }}$ subs. & $\begin{array}{l}\text { Whole } \\
\text { Period }\end{array}$ & $1^{\text {st }}$ subs. & $2^{\text {nd }}$ subs. & $\begin{array}{l}\text { Whole } \\
\text { Period }\end{array}$ & $1^{\text {st }}$ subs. & $2^{\text {nd }}$ subs. \\
\hline CHINA & $\begin{array}{c}-0.06 \\
(0.061)\end{array}$ & $\begin{array}{c}-0.02 \\
(0.083)\end{array}$ & $\begin{array}{c}-0.14 \\
(0.103)\end{array}$ & $\begin{array}{c}-0.02 \\
(0.058)\end{array}$ & $\begin{array}{c}0.07 \\
(0.071)\end{array}$ & $\begin{array}{l}-0.24^{*} \\
(0.105)\end{array}$ & $\begin{array}{c}0.05 \\
(0.068)\end{array}$ & $\begin{array}{c}0.12 \\
(0.082)\end{array}$ & $\begin{array}{l}-0.25^{*} \\
(0.118) \\
\end{array}$ \\
\hline HONG KONG & $\begin{array}{c}-0.15^{* *} \\
(0.067) \\
\end{array}$ & $\begin{array}{c}-0.36^{* *} \\
(0.151) \\
\end{array}$ & $\begin{array}{c}-0.10 \\
(0.120) \\
\end{array}$ & $\begin{array}{c}-0.09 \\
(0.076) \\
\end{array}$ & $\begin{array}{c}-0.08 \\
(0.160) \\
\end{array}$ & $\begin{array}{c}-0.10 \\
(0.109)\end{array}$ & $\begin{array}{c}-0.11 * * \\
(0.054) \\
\end{array}$ & $\begin{array}{c}-0.21 * * \\
(0.095) \\
\end{array}$ & $\begin{array}{c}-0.11 \\
(0.088) \\
\end{array}$ \\
\hline INDIA & $\begin{array}{c}0.04 \\
(0.060)\end{array}$ & $\begin{array}{c}-0.07 \\
(0.090)\end{array}$ & $\begin{array}{c}0.08 \\
(0.112)\end{array}$ & $\begin{array}{c}0.03 \\
(0.071)\end{array}$ & $\begin{array}{c}-0.07 \\
(0.109)\end{array}$ & $\begin{array}{c}0.07 \\
(0.133)\end{array}$ & $\begin{array}{c}0.02 \\
(0.072)\end{array}$ & $\begin{array}{c}-0.01 \\
(0.100)\end{array}$ & $\begin{array}{c}-0.04 \\
(0.105)\end{array}$ \\
\hline INDONESIA & $\begin{array}{c}0.06 \\
(0.061) \\
\end{array}$ & $\begin{array}{c}-0.13 \\
(0.098)\end{array}$ & $\begin{array}{c}0.13 \\
(0.122) \\
\end{array}$ & $\begin{array}{c}0.07 \\
(0.066) \\
\end{array}$ & $\begin{array}{c}0.01 \\
(0.122) \\
\end{array}$ & $\begin{array}{c}0.04 \\
(0.103) \\
\end{array}$ & $\begin{array}{c}-0.04 \\
(0.071) \\
\end{array}$ & $\begin{array}{c}-0.06 \\
(0.097) \\
\end{array}$ & $\begin{array}{c}-0.09 \\
(0.120) \\
\end{array}$ \\
\hline MALAYSIA & $\begin{array}{c}-0.06 \\
(0.070)\end{array}$ & $\begin{array}{c}-0.05 \\
(0.104)\end{array}$ & $\begin{array}{c}-0.16 \\
(0.127)\end{array}$ & $\begin{array}{c}-0.05 \\
(0.079)\end{array}$ & $\begin{array}{c}0.07 \\
(0.122)\end{array}$ & $\begin{array}{l}-0.16^{*} \\
(0.091)\end{array}$ & $\begin{array}{c}0.00 \\
(0.062)\end{array}$ & $\begin{array}{c}-0.08 \\
(0.107)\end{array}$ & $\begin{array}{c}0.04 \\
(0.094)\end{array}$ \\
\hline PHILIPPINES & $\begin{array}{c}-0.09 \\
(0.071)\end{array}$ & $\begin{array}{c}-0.26^{* *} \\
(0.121) \\
\end{array}$ & $\begin{array}{c}0.05 \\
(0.101) \\
\end{array}$ & $\begin{array}{c}-0.03 \\
(0.072)\end{array}$ & $\begin{array}{c}-0.13 \\
(0.114)\end{array}$ & $\begin{array}{c}0.04 \\
(0.119) \\
\end{array}$ & $\begin{array}{c}-0.04 \\
(0.068) \\
\end{array}$ & $\begin{array}{c}-0.09 \\
(0.122) \\
\end{array}$ & $\begin{array}{c}-0.05 \\
(0.092) \\
\end{array}$ \\
\hline SINGAPORE & $\begin{array}{c}-0.04 \\
(0.055) \\
\end{array}$ & $\begin{array}{c}-0.13 \\
(0.091)\end{array}$ & $\begin{array}{c}-0.05 \\
(0.163) \\
\end{array}$ & $\begin{array}{c}-0.02 \\
(0.068) \\
\end{array}$ & $\begin{array}{c}-0.05 \\
(0.122) \\
\end{array}$ & $\begin{array}{c}-0.01 \\
(0.104)\end{array}$ & $\begin{array}{c}-0.10 \\
(0.081)\end{array}$ & $\begin{array}{c}-0.18 \\
(0.133)\end{array}$ & $\begin{array}{c}-0.07 \\
(0.062)\end{array}$ \\
\hline SOUTH KOREA & $\begin{array}{c}0.02 \\
(0.075)\end{array}$ & $\begin{array}{c}0.05 \\
(0.079)\end{array}$ & $\begin{array}{c}0.03 \\
(0.083)\end{array}$ & $\begin{array}{c}-0.02 \\
(0.066)\end{array}$ & $\begin{array}{c}0.01 \\
(0.115)\end{array}$ & $\begin{array}{c}-0.03 \\
(0.092)\end{array}$ & $\begin{array}{c}0.10 \\
(0.0090)\end{array}$ & $\begin{array}{c}0.15 \\
(0.050)\end{array}$ & $\begin{array}{c}-0.04 \\
(0.129)\end{array}$ \\
\hline TAIWAN & $\begin{array}{c}-0.02 \\
(0.078)\end{array}$ & $\begin{array}{c}0.00 \\
(0.110) \\
\end{array}$ & $\begin{array}{c}-0.03 \\
(-0.14,0.11)\end{array}$ & $\begin{array}{c}-0.08 \\
(0.065) \\
\end{array}$ & $\begin{array}{c}-0.09 \\
(0.137) \\
\end{array}$ & $\begin{array}{c}-0.08 \\
(0.077) \\
\end{array}$ & $\begin{array}{c}-0.13 * * * \\
(0.072) \\
\end{array}$ & $\begin{array}{c}-0.12 \\
(-0.31,0.10)\end{array}$ & $\begin{array}{l}-0.30^{*} \\
(0.080) \\
\end{array}$ \\
\hline THAILAND & $\begin{array}{l}-0.17 * * \\
(0.071)\end{array}$ & $\begin{array}{l}-0.24 * * \\
(0.114)\end{array}$ & $\begin{array}{c}-0.04 \\
(0.135)\end{array}$ & $\begin{array}{l}-0.19^{* *} \\
(0.087)\end{array}$ & $\begin{array}{l}-0.27 * * \\
(0.124)\end{array}$ & $\begin{array}{c}-0.05 \\
(0.136)\end{array}$ & $\begin{array}{l}-0.13^{* *} \\
(0.059)\end{array}$ & $\begin{array}{c}0.33 * \\
(0.134)\end{array}$ & $\begin{array}{c}-0.16 \\
(0.121)\end{array}$ \\
\hline
\end{tabular}

Note: The same as for Table 1. 
A comparison of the pre- and post-crisis results shows an increase in d for Hong Kong, Indonesia, the Philippines, and Thailand vis-à-vis the US. $d$ also increases in the case of Thailand, while it decreases in the case of China and Malaysia vis-à-vis Japan; it increases for Hong Kong and Thailand as well and decreases for China and Taiwan when the regional index is used for the analysis. Therefore, Thailand seems to move away from both regional and global integration while China appears to have become integrated regionally during the post-crisis period.

\section{Consumer goods sector}

For this sector (Table 3) during the whole sample period (Columns (1), (4), and (7)), most estimated values of $\mathrm{d}$ imply $\mathrm{I}(0)$ stationarity, although there are some cases of long memory $(d>0)$ or high persistence; namely, Indonesia vis-à-vis the US and Japan, the Philippines vis-à-vis Japan and Asia, and Thailand vis-à-vis Japan. No evidence of anti-persistence or mean

Table 3. Estimates of $d$ for the Whole Period (2000M1-2016M8) and Two Sub-Samples (2000M1-2007M12, 2009M1-2016M12): Consumer Goods Sector Data

\begin{tabular}{|c|c|c|c|c|c|c|c|c|c|}
\hline & \multicolumn{9}{|c|}{ Consumer Goods sector } \\
\hline & \multicolumn{3}{|c|}{ Against US } & \multicolumn{3}{|c|}{ Against Japan } & \multicolumn{3}{|c|}{ Against Asia regional index } \\
\hline & (1) & (2) & (3) & (4) & (5) & (6) & (7) & (8) & (9) \\
\hline & $\begin{array}{l}\text { Whole } \\
\text { Period }\end{array}$ & $1^{\text {st }}$ subs. & $2^{\text {nd }}$ subs. & $\begin{array}{l}\text { Whole } \\
\text { Period }\end{array}$ & $1^{\text {st }}$ subs. & $2^{\text {nd }}$ subs. & $\begin{array}{l}\text { Whole } \\
\text { Period }\end{array}$ & $1^{\text {st }}$ subs. & $2^{\text {nd }}$ subs. \\
\hline CHINA & $\begin{array}{c}0.04 \\
(0.081)\end{array}$ & $\begin{array}{c}0.05 \\
(0.121)\end{array}$ & $\begin{array}{c}0.07 \\
(0.139)\end{array}$ & $\begin{array}{c}0.01 \\
(0.059)\end{array}$ & $\begin{array}{c}0.03 \\
(0.094)\end{array}$ & $\begin{array}{c}0.02 \\
(0.134)\end{array}$ & $\begin{array}{c}0.11 \\
(0.069)\end{array}$ & $\begin{array}{c}0.15 \\
(0.073)\end{array}$ & $\begin{array}{c}0.01 \\
(0.132)\end{array}$ \\
\hline HONG KONG & $\begin{array}{c}0.03 \\
(0.079)\end{array}$ & $\begin{array}{c}-0.07 \\
(0.105)\end{array}$ & $\begin{array}{c}0.10 \\
(0.128)\end{array}$ & $\begin{array}{c}0.04 \\
(0.062) \\
\end{array}$ & $\begin{array}{c}0.01 \\
(0.105)\end{array}$ & $\begin{array}{c}-0.01 \\
(0.122)\end{array}$ & $\begin{array}{c}-0.09 \\
(0.068)\end{array}$ & $\begin{array}{c}-0.11 \\
(0.085) \\
\end{array}$ & $\begin{array}{c}0.01 \\
(0.114) \\
\end{array}$ \\
\hline INDIA & $\begin{array}{c}0.04 \\
(0.058)\end{array}$ & $\begin{array}{c}0.05 \\
(0.090)\end{array}$ & $\begin{array}{c}-0.09 \\
(0.122)\end{array}$ & $\begin{array}{c}0.06 \\
(0.074)\end{array}$ & $\begin{array}{c}0.06 \\
(0.099)\end{array}$ & $\begin{array}{c}0.06 \\
(0.141)\end{array}$ & $\begin{array}{c}0.03 \\
(0.073)\end{array}$ & $\begin{array}{c}0.00 \\
(0.091)\end{array}$ & $\begin{array}{c}0.07 \\
(0.149)\end{array}$ \\
\hline INDONESIA & $\begin{array}{c}0.14 \\
(0.090)\end{array}$ & $\begin{array}{c}0.12 \\
(0.119)\end{array}$ & $\begin{array}{c}0.17 \\
(0.107)\end{array}$ & $\begin{array}{c}0.14 \\
(0.085)\end{array}$ & $\begin{array}{c}0.21 \\
(0.154)\end{array}$ & $\begin{array}{c}0.08 \\
(0.109)\end{array}$ & $\begin{array}{c}0.04 \\
(0.105)\end{array}$ & $\begin{array}{c}0.08 \\
(0.097)\end{array}$ & $\begin{array}{c}-0.13 \\
(0.145)\end{array}$ \\
\hline MALAYSIA & $\begin{array}{c}-0.02 \\
(0.066)\end{array}$ & $\begin{array}{c}-0.06 \\
(0.091)\end{array}$ & $\begin{array}{c}0.01 \\
(0.122)\end{array}$ & $\begin{array}{c}0.05 \\
(0.057)\end{array}$ & $\begin{array}{c}0.04 \\
(0.095)\end{array}$ & $\begin{array}{c}0.06 \\
(0.091)\end{array}$ & $\begin{array}{c}0.05 \\
(0.061)\end{array}$ & $\begin{array}{c}-0.03 \\
(0.109)\end{array}$ & $\begin{array}{c}0.17 \\
(0.098)\end{array}$ \\
\hline PHILIPPINES & $\begin{array}{c}0.05 \\
(0.121)\end{array}$ & $\begin{array}{c}0.01 \\
(0.095)\end{array}$ & $\begin{array}{c}0.08 \\
(0.103)\end{array}$ & $\begin{array}{c}0.08 \\
(0.064)\end{array}$ & $\begin{array}{c}-0.02 \\
(0.095)\end{array}$ & $\begin{array}{c}0.14 \\
(0.091)\end{array}$ & $\begin{array}{c}0.14 \\
(0.086)\end{array}$ & $\begin{array}{c}0.01 \\
(0.138)\end{array}$ & $\begin{array}{c}0.09 \\
(0.146)\end{array}$ \\
\hline SINGAPORE & $\begin{array}{c}0.00 \\
(0.083)\end{array}$ & $\begin{array}{c}-0.10 \\
(0.126)\end{array}$ & $\begin{array}{c}0.04 \\
(0.085)\end{array}$ & $\begin{array}{c}0.03 \\
(0.088)\end{array}$ & $\begin{array}{c}0.03 \\
(0.139)\end{array}$ & $\begin{array}{c}0.07 \\
(0.090)\end{array}$ & $\begin{array}{c}-0.03 \\
(0.079)\end{array}$ & $\begin{array}{c}-0.09 \\
(0.152)\end{array}$ & $\begin{array}{c}-0.14 \\
(0.103)\end{array}$ \\
\hline SOUTH KOREA & $\begin{array}{c}0.00 \\
(0.073)\end{array}$ & $\begin{array}{c}-0.04 \\
(0.137)\end{array}$ & $\begin{array}{c}0.01 \\
(0.091)\end{array}$ & $\begin{array}{c}0.03 \\
(0.073)\end{array}$ & $\begin{array}{c}-0.03 \\
(0.137)\end{array}$ & $\begin{array}{c}0.11 \\
(0.087)\end{array}$ & $\begin{array}{c}-0.02 \\
(0.085)\end{array}$ & $\begin{array}{c}-0.02 \\
(0.109)\end{array}$ & $\begin{array}{c}-0.13 \\
(0.103)\end{array}$ \\
\hline TAIWAN & $\begin{array}{c}0.04 \\
(0.0074)\end{array}$ & $\begin{array}{c}0.03 \\
(0.090)\end{array}$ & $\begin{array}{c}0.12 \\
(0.085) \\
\end{array}$ & $\begin{array}{c}-0.01 \\
(0.120)\end{array}$ & $\begin{array}{c}0.00 \\
(0.100)\end{array}$ & $\begin{array}{c}0.01 \\
(0.109) \\
\end{array}$ & $\begin{array}{c}-0.06 \\
(0.080)\end{array}$ & $\begin{array}{c}-0.01 \\
(0.110) \\
\end{array}$ & $\begin{array}{c}-0.23^{* *} \\
(0.109)\end{array}$ \\
\hline THAILAND & $\begin{array}{c}0.08 \\
(0.076)\end{array}$ & $\begin{array}{c}0.02 \\
(0.096)\end{array}$ & $\begin{array}{c}0.05 \\
(0.106)\end{array}$ & $\begin{array}{c}0.13 \\
(0.066)\end{array}$ & $\begin{array}{c}0.05 \\
(0.075)\end{array}$ & $\begin{array}{c}0.24 \\
(0.128)\end{array}$ & $\begin{array}{c}0.07 \\
(0.072)\end{array}$ & $\begin{array}{c}-0.03 \\
(0.134)\end{array}$ & $\begin{array}{c}0.01 \\
(0.128)\end{array}$ \\
\hline
\end{tabular}

Note: The same as for Table 1 . 
reversion is found in any case.

The sub-sample results in the rest of the columns in Table 3 provide evidence of regional integration only for Taiwan vis-à-vis Asia during the post-crisis period (in Column (9)), while there is no evidence of global integration. There are various cases of long memory in the post-crisis period - namely, Indonesia vis-à-vis the US; the Philippines, South Korea, and Thailand vis-à-vis Japan; and India and Malaysia vis-à-vis Asia - but only two in the pre-crisis period; namely, India vis-à-vis Japan and China vis-à-vis Asia. Overall, there is limited evidence of integration and only at the regional level, with long memory being found in more cases after the crisis.

Comparing the pre- and post-crisis periods, the estimated value of $d$ increases only for Indonesia vis-à-vis the US and for the Philippines, South Korea, and Thailand vis-à-vis Japan. Finally, $d$ increases in the case of India and Malaysia and decreases in the case of China and Taiwan when the regional index is used as a benchmark. Therefore, several emerging countries appear to be moving away from integration, either globally or regionally, with China and Taiwan being the exceptions.

\section{Financial sector}

For the financial sector (Table 4), full-sample evidence of long memory is found for Indonesia vis-à-vis the US (in Column (1)) and Japan (in Column (4)) and of mean reversion for Thailand vis-à-vis Asia (in Column (7)). In the pre-crisis period, there is only one case of mean reversion, namely, Thailand vis-à-vis Asia (see Column (8)), while in the post-crisis period, six economies (i.e., China, the Philippines, Singapore, South Korea, Taiwan, and Thailand) exhibit mean reversion vis-à-vis Asia (see Column (9)). After the crisis, there is only one case of mean reversion vis-à-vis the US, namely, that of China, and none vis-à-vis Japan. The only post-crisis case of long memory is that of India vis-à-vis Japan. The sub-sample analysis provides strong evidence of integration at the regional level after the 2008 crisis when using the regional rather than the Japanese index.

Examining the pre- and post-crisis periods, the estimated value of $d$ decreases only in the case of China vis-à-vis the US, and it increases in the case of India vis-à-vis Japan. When the regional index is used, it declines in various cases - China, the Philippines, Singapore, South Korea, Taiwan, and Thailand-which implies stronger regional integration in the post-crisis period.

Overall, in all three sectors examined, regional integration appears to be growing stronger despite some degree of heterogeneity. This is particularly apparent in the case of the financial sector: there is only one case of regional integration in the full sample during the pre-crisis period (Thailand vis-à-vis the Asian index, excluding Japan), but in the post-crisis period, 6 of the 10 economies examined exhibit regional integration (again, vis-à-vis the Asian index, 
excluding Japan), while there is only one case of global integration, namely, China (which is also regionally integrated). The Asian financial sector is dominated by banks that often focus on the traditional bank business of deposits and consumer lending to households and companies; they rely less on lending to other banks and selling financial derivatives, which was an advantage during the global financial crisis, during which dependence on borrowing from other banks became a major problem in the US and Europe as markets froze (Bhattacharya et al., 2015). The growing regional integration could be a reflection of developing Asian economies' even stronger reliance on traditional banking, which is perceived to be safer and less risky after the crisis.

For the industrial sector, there is slightly stronger regional than global integration for the whole sample period, with much weaker global integration and slightly stronger regional integration in the second sub-sample (mainly reflecting the stronger integration of China). While trade linkages within the region have continued to strengthen, foreign direct investments (FDI)

Table 4. Estimates of $d$ for the Whole Period (2000M1-2016M8) and Two Sub-Samples (2000M1-2007M12, 2009M1-2016M12): Financial Sector Data

\begin{tabular}{|c|c|c|c|c|c|c|c|c|c|}
\hline & \multicolumn{9}{|c|}{ Financial sector } \\
\hline & \multicolumn{3}{|c|}{ Against US } & \multicolumn{3}{|c|}{ Against Japan } & \multicolumn{3}{|c|}{ Against Asia regional index } \\
\hline & $(1)$ & (2) & (3) & (4) & (5) & (6) & (7) & (8) & (9) \\
\hline & $\begin{array}{l}\text { Whole } \\
\text { Period }\end{array}$ & $1^{\text {st }}$ subs. & $2^{\text {nd }}$ subs. & $\begin{array}{l}\text { Whole } \\
\text { Period }\end{array}$ & $1^{\text {st }}$ subs. & $2^{\text {nd }}$ subs. & $\begin{array}{l}\text { Whole } \\
\text { Period }\end{array}$ & $1^{\text {st }}$ subs. & $2^{\text {nd }}$ subs. \\
\hline CHINA & $\begin{array}{c}-0.05 \\
(0.060)\end{array}$ & $\begin{array}{c}0.02 \\
(0.090)\end{array}$ & $\begin{array}{l}-0.20 * * \\
(0.098)\end{array}$ & $\begin{array}{c}0.01 \\
(0.063)\end{array}$ & $\begin{array}{c}0.10 \\
(0.099)\end{array}$ & $\begin{array}{c}-0.09 \\
(0.098)\end{array}$ & $\begin{array}{c}0.05 \\
(0.059)\end{array}$ & $\begin{array}{c}0.08 \\
(0.082)\end{array}$ & $\begin{array}{l}-0.28 * * \\
(0.114)\end{array}$ \\
\hline HONG KONG & $\begin{array}{c}-0.07 \\
(0.049)\end{array}$ & $\begin{array}{c}-0.12 \\
(0.087)\end{array}$ & $\begin{array}{c}-0.19 \\
(0.138)\end{array}$ & $\begin{array}{c}0.00 \\
(0.079) \\
\end{array}$ & $\begin{array}{c}0.07 \\
(0.154) \\
\end{array}$ & $\begin{array}{c}0.03 \\
(0.104) \\
\end{array}$ & $\begin{array}{c}-0.06 \\
(0.060) \\
\end{array}$ & $\begin{array}{c}-0.12 \\
(0.103)\end{array}$ & $\begin{array}{c}-0.12 \\
(0.107)\end{array}$ \\
\hline INDIA & $\begin{array}{c}0.02 \\
(0.079) \\
\end{array}$ & $\begin{array}{c}0.00 \\
(0.126)\end{array}$ & $\begin{array}{c}0.01 \\
(0.121) \\
\end{array}$ & $\begin{array}{c}0.09 \\
(0.073) \\
\end{array}$ & $\begin{array}{c}0.06 \\
(0.123) \\
\end{array}$ & $\begin{array}{c}0.17 \\
(0.126) \\
\end{array}$ & $\begin{array}{c}-0.06 \\
(0.079) \\
\end{array}$ & $\begin{array}{c}-0.03 \\
(0.130) \\
\end{array}$ & $\begin{array}{c}-0.10 \\
(0.108) \\
\end{array}$ \\
\hline INDONESIA & $\begin{array}{c}0.13 \\
(0.061)\end{array}$ & $\begin{array}{c}0.03 \\
(0.128)\end{array}$ & $\begin{array}{c}0.11 \\
(0.147)\end{array}$ & $\begin{array}{c}0.09 \\
(0.071)\end{array}$ & $\begin{array}{c}0.06 \\
(0.091)\end{array}$ & $\begin{array}{c}0.05 \\
(0.097)\end{array}$ & $\begin{array}{c}0.06 \\
(0.090)\end{array}$ & $\begin{array}{c}0.06 \\
(0.153)\end{array}$ & $\begin{array}{c}-0.10 \\
(0.091)\end{array}$ \\
\hline MALAYSIA & $\begin{array}{c}0.07 \\
(0.080)\end{array}$ & $\begin{array}{c}0.11 \\
(0.127)\end{array}$ & $\begin{array}{c}-0.11 \\
(0.129)\end{array}$ & $\begin{array}{c}0.05 \\
(0.068)\end{array}$ & $\begin{array}{c}0.05 \\
(0.092)\end{array}$ & $\begin{array}{c}0.01 \\
(0.091)\end{array}$ & $\begin{array}{c}0.04 \\
(0.073)\end{array}$ & $\begin{array}{c}0.08 \\
(0.152)\end{array}$ & $\begin{array}{c}0.07 \\
(0.099)\end{array}$ \\
\hline PHILIPPINES & $\begin{array}{c}0.01 \\
(0.067)\end{array}$ & $\begin{array}{c}-0.16 \\
(0.128)\end{array}$ & $\begin{array}{c}-0.06 \\
(0.122)\end{array}$ & $\begin{array}{c}0.05 \\
(0.050)\end{array}$ & $\begin{array}{c}-0.02 \\
(0.108)\end{array}$ & $\begin{array}{c}0.03 \\
(0.093)\end{array}$ & $\begin{array}{c}-0.09 \\
(0.078)\end{array}$ & $\begin{array}{c}-0.07 \\
(0.134)\end{array}$ & $\begin{array}{c}-0.15^{* *} \\
(0.063)\end{array}$ \\
\hline SINGAPORE & $\begin{array}{c}-0.02 \\
(0.052) \\
\end{array}$ & $\begin{array}{c}-0.17 \\
(0.110) \\
\end{array}$ & $\begin{array}{c}-0.14 \\
(0.097) \\
\end{array}$ & $\begin{array}{c}0.03 \\
(0.074) \\
\end{array}$ & $\begin{array}{c}0.03 \\
(0.146) \\
\end{array}$ & $\begin{array}{c}0.07 \\
(0.086) \\
\end{array}$ & $\begin{array}{c}-0.08 \\
(0.106) \\
\end{array}$ & $\begin{array}{c}-0.03 \\
(0.145) \\
\end{array}$ & $\begin{array}{c}-0.31 * * * \\
(0.146) \\
\end{array}$ \\
\hline $\begin{array}{l}\text { SOUTH } \\
\text { KOREA }\end{array}$ & $\begin{array}{c}0.01 \\
(0.067)\end{array}$ & $\begin{array}{c}0.01 \\
(0.112)\end{array}$ & $\begin{array}{c}-0.09 \\
(0.098) \\
\end{array}$ & $\begin{array}{c}0.00 \\
(0.075) \\
\end{array}$ & $\begin{array}{c}0.01 \\
(0.137) \\
\end{array}$ & $\begin{array}{c}0.02 \\
(0.086)\end{array}$ & $\begin{array}{c}-0.03 \\
(0.090) \\
\end{array}$ & $\begin{array}{c}0.01 \\
(0.103) \\
\end{array}$ & $\begin{array}{c}-0.24 * * * \\
(0.136) \\
\end{array}$ \\
\hline TAIWAN & $\begin{array}{c}-0.03 \\
(0.086)\end{array}$ & $\begin{array}{c}-0.08 \\
(0.133)\end{array}$ & $\begin{array}{c}-0.13 \\
(0.060)\end{array}$ & $\begin{array}{c}-0.04 \\
(0.075)\end{array}$ & $\begin{array}{c}-0.04 \\
(0.121)\end{array}$ & $\begin{array}{c}-0.07 \\
(0.093)\end{array}$ & $\begin{array}{c}-0.12 \\
(0.072)\end{array}$ & $\begin{array}{c}-0.18 \\
(0.155)\end{array}$ & $\begin{array}{l}-0.27^{*} \\
(0.092)\end{array}$ \\
\hline THAILAND & $\begin{array}{c}-0.04 \\
(0.060)\end{array}$ & $\begin{array}{c}-0.09 \\
(0.109)\end{array}$ & $\begin{array}{c}-0.14 \\
(0.139)\end{array}$ & $\begin{array}{c}-0.01 \\
(0.067)\end{array}$ & $\begin{array}{c}-0.10 \\
(0.109)\end{array}$ & $\begin{array}{c}0.03 \\
(0.114)\end{array}$ & $\begin{array}{l}-0.20^{*} \\
(0.061)\end{array}$ & $\begin{array}{l}-0.23 * * \\
(0.099)\end{array}$ & $\begin{array}{c}-0.29 * * * \\
(0.161)\end{array}$ \\
\hline
\end{tabular}

Note: The same as for Table 1 . 
within Asia have also been increasing as the development of technology, human resources, and capital accumulation have enabled many economies in the region to invest and establish production in neighboring countries (Asian Development Bank, 2016). Strengthened trade and investment linkages may have contributed to stronger regional integration in the industrial sector, especially after the crisis, when demand and FDI from the developed world slowed down. As for the consumer goods sector, there is no evidence of global integration and very limited evidence of regional integration. This is not surprising since domestic factors tend to play a bigger role in this case.

On the whole, the sectoral analysis suggests that while some sectors (e.g., the financial sector) contributed to integration at the aggregate level, others (e.g., the consumer goods sector) held it back. Furthermore, Japan does not appear to be a regional leader, since regional integration is only observed when using the regional price index (excluding Japan) rather than the Japanese price index (with only a few exceptions), while China is becoming increasingly integrated, especially after the 2008 crisis (at the regional level for the industrial sector and both regionally and globally for the financial sector). Hong Kong, Taiwan, and Thailand are among the most regionally integrated economies.

\section{Conclusions}

This paper investigates the issue of the global and regional financial integration of 10 emerging Asian economies at both the aggregate and industry levels, analyzing the stochastic behavior of stock return differentials by means of fractional integration techniques. Our main findings are as follows. First, there is overwhelming evidence of regional integration being stronger than global integration at the aggregate level. The sub-period analysis shows that during the pre-2008 crisis period, global integration was stronger than regional integration, while the opposite is true of the post-crisis period. Second, stronger evidence of regional integration is found at the industry level, especially during the post-crisis period, for the financial sector. Our industry-level analysis also highlights that integration is heterogeneous across industries. Third, regional integration in emerging Asia is mainly within economies other than Japan; China appear to be more integrated both globally and regionally after the 2008 crisis, and Hong Kong, Taiwan, and Thailand are the most regionally integrated countries.

Our first finding of stronger regional integration is in contrast to the conclusions of numerous other studies that discovered more evidence of global integration (e.g., Hinojales \& Park, 2011; Park \& Lee, 2011; Kim et al., 2011; Kim \& Lee, 2012; Park, 2013), but is consistent with the results of Wang (2014) for the post-2008 crisis period. This could reflect the various regional agreements signed over recent years (e.g., the Chiang Mai Initiative in 2000, the Asian Bond 
Market Initiative (ABMI) in 2003, the new ABMI roadmap in 2008, and the Chiang Mai Initiative Multilateralization in 2012) to promote financial cooperation in the region. The 2008 financial crisis provided further incentive for greater regional integration to deal with external common shocks (Asian Development Bank, 2013). Therefore, an important policy implication of our findings is that regional cooperation should be continued and even intensified, if possible.

The immediate and sizable adverse effects of the 2008 global financial crisis on Asian stock markets also highlight the crucial role played by shifts in investors' risk profile. While the developed economies were mainly hit by liquidity shock, emerging equity markets were primarily affected by a decline in risk appetite (Chudik \& Fratzscher, 2011), regardless of their level of financial integration with developed economies (Wang, 2014). Therefore, despite the declining level of global integration after the 2008 crisis, policymakers in emerging Asian economies should establish a framework to assess and monitor this type of financial crisis transmission mechanism (e.g., the daily measures of risk appetite proposed by Kumar \& Persaud, 2002) to be able to react quickly and effectively.

Our industry-level analysis suggests that the financial sector is highly regionally integrated, while its integration with the US or other countries in the region such as Japan has been declining, especially after the 2008 crisis, which is consistent with the findings of Hinojales and Park (2011). Therefore, the Asian stock markets could be an attractive option for investors seeking global portfolio diversification. By contrast, regional diversification does not seem to be achievable, given the evidence of strong regional integration, in China, Hong Kong, Taiwan, and Thailand.

\section{References}

Abid, I., Kaabia, O., \& Guesmi, K. (2014). Stock market integration and risk premium: Empirical evidence for emerging economies of South Asia. Economic Modelling, 37, 408-416.

Almekinders, G., Fukuda, S., Mourmouras, A., Zhou, J., \& Zhou, Y. S. (2015). ASEAN Financial Integration. IMF Working Paper 15/34. Washington, DC: International Monetary Fund.

Ananchotikul, N., Piao, S., \& Zoli, E. (2015). Drivers of financial integration - implications for Asia. IMF Working Paper 15/60. Washington, DC: International Monetary Fund.

Asian Development Bank. (2013, October). Regional cooperation and integration. In Asian Development Bank (Ed.), Asian Economic Integration Monitor (pp. 9-33). Asian Development Bank.

Asian Development Bank. (2016). Special Theme Chapter: What Drives Foreign Direct Investment in Asia and the Pacific? Asia Economic Integration Report. Manila: Asian Development Bank.

Baele, L., Fernando, A., Hordahl, P., Krylova, E., \& Monnet, C. (2004). Measuring financial integration in the Euro area. ECB Occasional Paper Series, No. 14.

Baltzer, M., Cappiello, L., De Santis, R. A., \& Manganelli, S. (2008). Measuring financial integration 
in new EU member states. ECB Occasional Paper Series, No. 81.

Bayoumi, T. (1997). Financial integration and real activity. Manchester University Press.

Bhattacharya, R., Han, F., \& Walsh, J. P. (2015). The Future of Asia's Financial Sector. In R. Sahay, J. Schiff, C. H. Lim, C. Sumi, \& J. P. Walsh (Eds.), The Future of Asian Finance, Washington, DC: IMF.

Boubakri, S., \& Guillaumin, C. (2015). Regional integration of the East Asian stock markets: An empirical assessment. Journal of International Money and Finance, 57, 136-160.

Cao, G., Zhang, M., \& Li, Q. (2017). Volatility-constrained multifractal detrended cross correlation analysis: Cross-correlation among Mainland China, US, and Hong Kong stock markets. Physica A, 472, 67-76.

Caporale, G. M., \& Gil-Alana, L. A. (2017). Persistence and cycles in the US Federal Funds rate. International Review of Financial Analysis, 52, 1-8.

Cavoli, T., Rajanb, R. S., \& Siregarc, R. (2006). Financial integration in East Asia: How far? How much further to go? eSocialSciences Working Papers, 372.

Chen, S.-L., \& Kim, H. (2011). Nonlinear Mean Reversion across National Stock Markets: Evidence from Emerging Asian Markets. International Economic Journal, 25(2), 239-250.

Chien, M.-S., Lee, C. C., Hu, T. C., \& Hu, H. T. (2015). Dynamic Asian stock market convergence: Evidence from dynamic cointegration analysis among China and ASEAN-5. Economic Modelling, $51,84-98$.

Chudik, A., \& Fratzscher, M. (2011). Identifying the global transmission of the 2007-2009 financial crisis in a GVAR model. European Economic Review, 55(3), 325-339.

Dahlhaus, R. (1989). Efficient parameter estimation for self-similar process. Annals of Statistics, 17, 1749-1766.

De Browuer, G. (1999). Financial integration in East Asia. Cambridge University Press.

Donadelli, M., \& Paradiso, M. (2014). Is there heterogeneity in financial integration dynamics? Evidence from country and industry emerging market equity indexes. Journal of International Financial Markets Institutions and Money, 32, 184-218.

Feldstein, M., \& Horioka, C. (1980). Domestic saving and international capital flows. Economic Journal, 90, 314-329.

Fung, L., Yu, I. W., \& Tam, C. S. (2008). Assessing the integration of Asian's equity and bond markets. In Bank for International Settlements (Ed.), Regional financial integration in Asia: Present and future (pp. 1-37). Bank for International Settlements.

Gil-Alana, L. A. (2000). Mean reversion in the real exchange rates. Economics Letters, 69, 285-288.

Gil-Alana, L. A. (2004). Long memory in the US interest rate. International Review of Financial Analysis, 13(3), 265-276.

Glick, R., \& Hutchison, M. (2013). China's financial linkages with Asia and the global financial crisis. Journal of International Money and Finance, 39, 186-206.

Granger, C. W. J. (1980). Long memory relationships and the aggregation of dynamic models. Journal of Econometrics, 14, 227-238.

Granger, C. W. J., \& Joyeux, R. (1980). An introduction to long memory time series and fractionally 
differencing. Journal of Time Series Analysis, 1, 15-29.

Grilli, V., \& Milesi-Ferretti, G. M. (1995). Economic effects and structural determinants of capital controls. IMF Staff Papers, 42, 517-551.

Grimes, W. W. (2009). Japan, the Global Financial Crisis, and the Stability of East Asia. In A. J. Tellis, A. Marble, \& T. Tanner (Eds.), Economic Meltdown and Geopolitical Stability (pp. 105-130). Washington, DC: The National Bureau of Asian Research.

Gupta, R., \& Guidi, F. (2012). Cointegration relationship and time varying co movements among Indian and Asian developed stock markets. International Review of Financial Analysis 21, 10-22.

He, D., Zhang, Z., \& Wang, H. (2009). Hong Kong's financial market interactions with the US and Mainland China in crisis and tranquil times. Hong Kong Monetary Authority Working Paper 10/2009. Hong Kong: Hong Kong Monetary Authority.

Hinojales, M., \& Park, C.-Y. (2011). Stock market integration: Emerging East Asia's experience. In M. Devereux, P. Lane, C. Y. Park, \& S. J. Wei (Eds.), The Dynamics of Asian Financial Integration: Facts and Analytics. Asian Development Bank.

Hosking, J. R. M. (1981). Fractional differencing. Biometrika, 68, 165-176.

Huyghebaert, N., \& Wang, L. (2010). The co-movement of stock markets in East Asia Did the 1997-1998 Asian financial crisis really strengthen stock market integration? China Economic Review, 21, 98-112.

Kearney, C., \& Lucey, B. M. (2004). Equity market integration: Theory, evidence and implications. International Review of Financial Analysis, 13(5), 571-583.

Kim, S., \& Lee, J.-W. (2012). Real and financial integration, real and financial integration in east Asia. Review of International Economics, 20(2), 332-349.

Kim, S., Lee, J. W., \& Park, C. Y. (2011). Emerging Asia: Decoupling or recoupling. The World Economy, 34(1), 23-53.

Kumar, M., \& Persaud, A. (2002). Pure contagion and investors' shifting risk appetite: Analytical issues and empirical evidence. International Finance, 5(3), 401-436.

Loh, L. (2013). Co-movement of Asia-Pacific with European and US stock market returns: A cross-time-frequency analysis. Research in International Business and Finance, 29, 1-13.

Magud, N., \& Reinhart, C. (2006). Capital controls: An evaluation. NBER Working Paper, 11973.

Narayan S., Sriananthakumar, S., \& Islam, S. Z. (2014). Stock market integration of emerging Asian economies: Patterns and causes. Economic Modelling, 39, 19-31.

Park, C.-Y. (2013). Asian capital market integration: theory and evidence. ADB Working Paper 351, Asian Development Bank 2013.

Park, C.-Y., \& Lee, J.-W. (2011). Financial integration in emerging Asia: Challenges and prospects. Asian Economic Policy Review, 6, 176-198.

Pauer, F. (2005). Financial market integration and financial stability. Monetary Policy and The Economy, 2, 144-151.

Robinson, P. M. (1978). Statistical inference for a random coefficient autoregressive model. Scandinavian Journal of Statistics, 5, 163-168.

Rughoo A., \& You, K. (2016). Asian financial integration: Global or regional? Evidence from money and bond markets. International Review of Financial Analysis, 48, 419-434. 
Schipke, A. (Ed.) (2015). Frontier Asia: The Next Generation of Emerging Markets. Washington: International Monetary Fund.

Sharma, A., \& Seth, N. (2012). Literature review of stock market integration: A global perspective. Qualitative Research in Financial Markets, 4(1), 84-122.

Stockman, A. C. (1988). On the roles of international financial markets and their relevance for economic policy. Journal of Money, Credit, and Banking, 20(3), 531-549.

Volosovych, V. (2011). Measuring financial market integration over the long run: Is there a U-shape? Journal of International Money and Finance, 30, 1535-1561.

Volosovych, V. (2013). Learning about financial market integration from principal components analysis. CESifo Economic Studies, 59(2), 360-391.

Wang, J., Zhang, D., \& Zhang, J. (2015). Mean reversion in stock prices of seven Asian stock markets: Unit root test and stationary test with Fourier functions. International Review of Economics and Finance, 37, 157-164.

Wang, L. (2014). Who moves East Asian stock markets? The role of the 2007-2009 global financial crisis. Journal of International Financial Markets, Institutions and Money, 28, 182-203.

Wang, Q., Zhu, Y., Yang, L., \& Mul, R. A. H. (2017). Coupling detrended fluctuation analysis of Asian stock markets. Physica A, 471, 337-350.

World Federation of Exchange. (2016). World Federation of Exchange Annual Statistical Guide 2016.

Wu, L., Meng, Q., \& Xu, K. (2015). 'Slow-burn' spillover and 'fast and furious' contagion: A study of international stock markets. Quantitative Finance, 15(6), 933-958.

Yang, J. (2010). Japan's decline relative to China: Scenarios and implications for East Asia. Political Science, 62(2), 146-165. 